BRITISH JUVENILE IMMIGRANTS IN CANADA 1868 TO 1939: A STUDY OF THE RELATIONSHIP BETWEEN SOCIETAL CHANGES AND THE TREATMENT OF HOME CHILDREN

by

Brianna Leigh Coombes, BA (Hon), University of Guelph, 2006

\author{
A Major Research Paper \\ presented to Ryerson University \\ in partial fulfillment of the requirements for the degree of \\ Master of Arts \\ In the Program of \\ Immigration and Settlement Studies
}

(C) Brianna Leigh Coombes, 2007 
UMI Number: EC53560

\section{INFORMATION TO USERS}

The quality of this reproduction is dependent upon the quality of the copy submitted. Broken or indistinct print, colored or poor quality illustrations and photographs, print bleed-through, substandard margins, and improper alignment can adversely affect reproduction.

In the unlikely event that the author did not send a complete manuscript and there are missing pages, these will be noted. Also, if unauthorized copyright material had to be removed, a note will indicate the deletion.

\section{$\mathrm{UMI}^{\circ}$}

UMI Microform EC53560

Copyright 2009 by ProQuest LLC

All rights reserved. This microform edition is protected against unauthorized copying under Title 17, United States Code.

ProQuest LLC

789 East Eisenhower Parkway

P.O. Box 1346

Ann Arbor, MI 48106-1346 


\section{Author's Declaration}

I hereby declare that I am the sole author of this major research paper.

I authorize Ryerson University to lend this paper to other institutions or individuals for the purpose of scholarly research.

Signature

I further authorize Ryerson University to reproduce this paper by photocopying or by other means, in total or in part, at the request of other institutions or individuals for the purpose of scholarly research.

Signature 


\title{
BRITISH JUVENILE IMMIGRANTS IN CANADA 1868 TO 1939: A STUDY OF THE RELATIONSHIP BETWEEN SOCIETAL CHANGES AND THE TREATMENT OF HOME CHILDREN
}

C Brianna Leigh Coombes, 2007

Master of Arts

Immigration and Settlement Studies

Ryerson University

\begin{abstract}
This paper examines the history of the British juvenile immigrants, a group of over 100,000 children who arrived in Canada between 1868 and 1939 to work on farms or as domestic workers. There was both a pressing need within Canada for farm workers, and overcrowding in British cities, therefore conditions were right for a mutually beneficial labour exchange between the two nations. British philanthropists encouraged this movement and ensured its continued success over a seventy year period. The societal changes that occurred in Canada during the same period as a result of the reform movement are also traced within this historical examination. The increase in child welfare policies, and the subsequent attitudinal changes in the Canadian public also impacted how the home children were treated and viewed. Through this research, this neglected group of immigrants will be given a more prominent position in Canadian social and immigration history.
\end{abstract}

Key Words:

Immigration; British juvenile immigrants; home children; philanthropy; child welfare; reform movement; social history 


\section{$\underline{\text { Acknowledgements }}$}

This paper has been both extremely challenging and extremely rewarding to write. Thank you to everyone who provided their support in any way on this project. I would especially like to thank:

My best friend and biggest supporter Kevin, who gave me the encouragement and confidence I needed to really get going and see it through until the end.

My wonderful professors at both the University of Guelph and Ryerson University who have been so dedicated and supportive to students like myself.

My friends and family who endured both my excitement and lack thereof with open minds and open ears.

My grandfather Rowlie Coombes and my great grandfather Leslie Coombes because their knowledge, passion, and experiences allowed my excitement and interest in this wonderful and important topic to be developed. 


\section{Table of Contents}

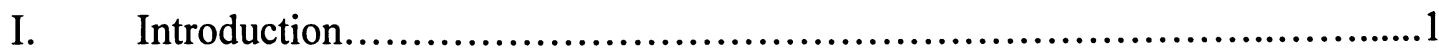

II. Industrial Revolution and British Philanthropy ...............................4

III. Transportation and Settlement..........................................27

IV. Reform Movement and Treatment of Home Children........................36

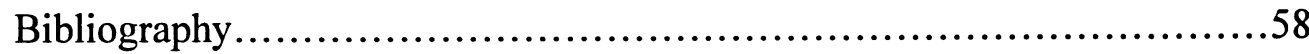




\section{Introduction}

In Canadian society the care of children and protection of their rights is a process we take for granted. There are seldom second thoughts on the part of most Canadians that children are a precious resource, and that every measure should be taken to see they are not in any way harmed. However, this was not always the case. Children immigrating to Canada in the $19^{\text {th }}$ and $20^{\text {th }}$ centuries routinely experienced numerous hardships. A group of nearly 100,000 children who experienced adversity in their lives came to Canada between 1868 and 1939 when concern for children was only beginning to develop. These were the British juvenile immigrants, who were also known as the "home children." These children came from many different backgrounds in Britain but they all had one thing in common. They came to Canada to work on farms or as domestic workers during a period of great change for the nation. It was a rural, agricultural nation that was developing into an economic and industrial power, and these children were often caught in the middle of societal changes that were occurring.

In many previous studies on the history of juvenile immigration in Canada, generalizations regarding the treatment of these children have been made. All children and time periods were grouped together to demonstrate that overall children were mistreated and were looked down upon by most in Canadian society. However, this is not the case. Many people were extremely happy that British children were arriving in Canada to assist with agricultural work, and to free other adults for industrial work. These immigrants were not all mistreated either; many had very happy and productive lives which were far better than those they would have been able to lead in Britain. 
Within this paper, the history of home children and the changes in their treatment over time will be examined. It can be seen through these changes and the policies enacted regarding the protection and welfare of children that the juvenile immigrants often endured maltreatment when economic or social situations were difficult in Canada. When changes regarding the treatment of children occurred within society or in the government, there was often a corresponding change in the way that the juvenile immigrants were viewed. This paper will illustrate that the harsh treatment of home children was due to the negative attitudes of Canadians at certain times in the juvenile immigration movement. As more measures were put into place to protect both Canadian and foreign children, the treatment of home children improved. This group of juvenile immigrants, so essential to Canada's agricultural development yet often neglected within Canadian history, will be given a more prominent position through this in-depth account of their treatment.

There are several reasons why this study is important and necessary to contribute to the immigration history of Canada. Firstly, although the study of home children is quite popular as a topic in social history, not much original research has been done in quite some time. Most previous research was undertaken and published in the 1970s or early 1980s. Some minor sources, such as a few articles and fictional accounts of home children, have been written since, yet they only serve to fill a few of the gaps that the more widely known sources do not cover. The only exception is Marjorie Kohli's 1999 book, The Golden Bridge which is current, thorough, and provides a great deal of information on the various organizations committed to child migration. 
This research paper will serve to tie together the major findings on home children which have been previously presented. Furthermore, the changes in Canadian society that occurred throughout the period of juvenile immigration to Canada will also be explored. It is important that the treatment of home children be viewed within its historical context. In terms of the child welfare practices in place today, the treatment the home children received seems unusually harsh. In the $19^{\text {th }}$ or early $20^{\text {th }}$ century when the children came to Canada, these practices were not in place and the treatment of these essential immigrants was much different. Therefore, this study should be looked upon not to diminish the hardships that the juvenile immigrants faced in their early years in Canada, but as an examination of why they experienced the treatment that they did.

Juvenile immigration was essential to Canada's success as an agricultural nation. In order to understand how social conditions within Canada contributed to the overall improvement of life for British immigrant children, a background on the development of child immigration is necessary. Examining the social history of both Britain and Canada allows for a better understanding of why each nation was so eager to participate in the program. The philanthropists born out of the Evangelical Movement who participated in child rescue must also be considered as they were the first individuals who brought children to Canada to work as farmhands or domestic servants. For a complete picture of child migration to Canada, a number of factors need addressing: the actual process of sending children to Canada; criticisms by society and the government; and the various policies enacted to protect the children. This background will give context to the major research on the treatment of home children during the $19^{\text {th }}$ and $20^{\text {th }}$ centuries in Canada, and will demonstrate the overall value of the program in contrast to its weaknesses. 


\section{Industrial Revolution and British Philanthropy}

In the early years of the $19^{\text {th }}$ century, Europe was experiencing the effects of the Industrial Revolution. Many people migrated to the cities in search of jobs, causing a large urban population increase. For example, the city of Glasgow increased from 43,000 people in 1780 to over 200,000 at the beginning of $1830 .{ }^{1}$ London was even more overcrowded, as the population doubled in size between 1821 and 1851 to over 2.3 million people, and nearly doubled again by the end of the century. ${ }^{2}$ This increase in city dwellers resulted in many negative side effects such as the proliferation of disease, crime, and poverty. Although many individuals came to the cities to find jobs, there were not enough to go around. In addition, the jobs available were low paying and often involved very long hours. Many families lived in extreme poverty, experiencing crowded, dirty conditions with very little proper food or clean water. Often these families could not survive without the assistance of every able worker in the family, forcing many young children into the workforce to help relieve the financial burden.

The jobs most commonly available to children were ones that required specialized skills adults could not perform. This included: "making lucifer matches, paper bags, flowers and clothing which required the agile and quick hands of children."3 Although these jobs required long hours and did not pay very high wages, the children's earnings made up for shortfalls in adult incomes. ${ }^{4}$ To provide another form of assistance to the family, some older children stayed home and looked after their younger siblings while their parents worked. Younger girls,

\footnotetext{
${ }^{1}$ Anna Magnusson, Quarriers Story, One man's Vision That Gave 7,000 Children a new Life in Canada (Toronto: Dundurn Press, 2006), 17.

${ }^{2}$ Gillian Wagner, Barnardo (London: Weidenfeld and Nicolson, 1979), 17.

${ }^{3}$ Joy Parr, Labouring Children: British Immigrant Apprentices to Canada, 1869-1924 (Montreal: McGill-Queen's University Press, 1980), 18.

${ }^{4}$ Peter Kirby, Child Labour in Britain, 1750-1870 (New York: Palgrave MacMillan, 2003), 31.
} 
especially those aged 6 to 12 , were entrusted with the care of infants and younger siblings. ${ }^{5}$ In homes with widows or widowers, young children were likely to have even greater responsibilities such as cooking, cleaning, and laundry, since there was only one parent to take on the burdens of two adults. Children in homes headed by a lone parent either took on another job or helped to run the household to keep it together. ${ }^{6}$ They were also more likely than other children to be working. According to labour historian Peter Kirby, in 1861, 23 per cent of the children with lone mothers worked outside of the home compared with 13 per cent of children in two parent families. ${ }^{7}$ In this time period living conditions were so poor that children were not even able to be children any more; "there was no childhood among the poor...only labour."8

In addition to the children who worked for wages in order to help their families, many children begged on the streets of Britain's major cities to support themselves. Disease and poverty were so prevalent that many children were orphaned at a young age, and thus were forced onto the streets to earn a meagre living. In the early days of the $19^{\text {th }}$ century, there was nowhere for these orphaned children to go except for the poor house, and many wanted to avoid this outcome. Children faced with poverty, abandonment, or who were orphaned at a young age did not have a promising future. Many died before reaching adulthood, and those who did reach maturity often ended up trapped in the cycle of poverty, taking on a low paying job similar to those of their own parents. ${ }^{9}$

\footnotetext{
${ }^{5}$ Parr, Labouring Children, 17.

${ }^{6}$ Ibid., 18.

${ }^{7}$ Kirby, Child Labour, 28.

${ }^{8}$ Parr, Labouring Children, 14.

9 Ibid., 15.
} 
Due to the overwhelming number of children on the streets of Britain in the early $19^{\text {th }}$ century, prominent members of society put forth the idea of sending children to the British colonies. In places such as Australia, New Zealand, and Canada, these children would be helpful as agricultural labourers, and would furthermore absolve Britain of the responsibility of caring for them. As early as 1825, Reverend Thomas Socket and the Honourable Peter Robinson presented this idea before parliament. ${ }^{10}$ In 1826 , William Henry Bodkin, a philanthropist, and Robert Chambers, a police magistrate, also proposed child emigration. Chambers was the first to share his thoughts on the idea as he presented them before a select committee of the British parliament:

I am of the opinion [that] such a system of emigration would be productive of great benefit. There has been a great increase, as I can show by returns now in my hand, of juvenile offences, which I attribute, first, to the increase of the population, secondly, to the want of employment for children....I think that...if the parents saw that government were going to take the children under its protection, and that there was a prospect of their future welfare, they would be glad to offer their children for that purpose. ${ }^{11}$

Furthermore, through the letters he received from officials of various municipalities in England, Chambers was of the opinion that "children who were down and out, those twelve years of age and upward, should be sent to Canada, where they were badly needed, to be apprenticed to persons who...would be glad to receive them as workers on the land." ${ }^{, 12}$ It was clear that the idea for child emigration was present far before the major movement of children to Canada took place, but it still required the persistence of reformers who could gain support of the wider public.

\footnotetext{
${ }^{10}$ Gail H. Corbett, Nation builders: Barnardo Children in Canada. $2^{\text {nd }}$ Ed. (Toronto, Dundurn Press, 2002), 23.

${ }^{11}$ Kenneth Bagnell, The Little Immigrants: The Orphans Who Came to Canada, New Edition (Toronto: The Dundurn Group, 2001), 26.

${ }^{12}$ Ibid., 26.
} 
The idea of child emigration as touted by Chambers and other reformers was not a unique one, but rather arose from the precedent set by the emigration of pauper children from Britain to the colonies in Virginia as indentured servants starting in $1618 .{ }^{13}$ Nearly one thousand children were sent to the Virginia Company throughout the $17^{\text {th }}$ century, and between 1800 and 1850 , several thousand children were sent to Australia until the Gold Rush there became too physically and morally dangerous for children. ${ }^{14}$ After this time, the idea of sending children to Canada developed. The first group of children was transported from Britain to Canada in 1830 as an independent movement, separate from the large-scale child emigration that began later. One dozen children came by way of the Children's Friend Society of London, and were placed on farms between Montreal and Niagara Falls. ${ }^{15}$ The early actions of British charitable societies sending small groups of children to Canada laid the foundation for the development of juvenile immigration schemes later in the $19^{\text {th }}$ century.

While Great Britain was suffering from overcrowding in the cities, the Dominion of Canada had a very small population and low population growth. Canada was seen as a "land of opportunities" where British children would make their way far away from a world inhabited by paupers where young people would acquire habits of public dependence. ${ }^{16}$ Because Canada was a developing agricultural nation, labour was very important to Canadian farmers. Furthermore, there was often a shortage of appropriate farm workers in the spring and summer months. The need for hired farm help and indoor domestic workers was felt acutely in Canada's developing

\footnotetext{
${ }^{13}$ Philip Bean and Joy Melville, Lost Children of the Empire (London: Unwin Hyman, 1989), 1.

${ }^{14}$ Ibid., 37-38.

${ }^{15}$ Corbett, Nation Builders, 23.

${ }^{16}$ Parr, Labouring Children, 31.
} 
years. ${ }^{17}$ In 1853, Samuel Strickland, an author and Canadian pioneer, was convinced that British children were the answer to the shortage of farm labourers in Canada. He felt that British citizens who were willing to work hard were needed most in Canada. In turn a life in Canada would provide more opportunities than one in Britain. He wrote in 1855:

We do not want the idle, the over-educated, the sickly. We want men, women, and children of hardy and industrious habits, who finding work slack at home, resolve to emulate the ants and bees, by leaving the parent hill or hive, for a land where their industry will furnish them abundantly with the necessities of life, and enable them to sit by their own chimney-corner to enjoy, in their peaceful old age, the happy home their toils have founded in the wilderness. ${ }^{18}$

Similarly, he suggested that the best child immigrants would be well-trained children from Britain; those who had attended industrial schools and had learned skills in agriculture, housework, dairy work, and mechanics. ${ }^{19}$ These skills would benefit both the colony and the children themselves, as they would be able to build a life in a place where they could be happy and successful. In order for the plan to work, Strickland suggested depots in Upper and Lower Canada's major cities for the children to stay in until they were apprenticed out by farmers for a three year term. He also suggested that each child be given a stipend of money or farming goods at the end of the term to help them get started with a farm of their own. Although these ideas were ahead of his time, Strickland made some important suggestions regarding the child immigration process, and it would be only a few years before children began arriving in Canada in large groups. ${ }^{20}$

\footnotetext{
${ }^{17}$ Marjorie Kohli, The Golden Bridge: Young Immigrants to Canada, 1833-1939 (Toronto: Natural Heritage Books, 2003), 14.

${ }^{18}$ Ibid., 16

${ }^{19}$ Ibid., 17.

${ }^{20}$ Ibid., 17.
} 
The major period of child immigration from Britain to Canada began in 1868 when Maria Rye, a British philanthropist, brought a small group of girls to Southern Ontario to become domestic workers. The movement had a slow start with only several hundred children coming to Canada each year for the first several years after 1868. After the mid 1870s, Rye brought an increasing number of children from Britain to Canada. While the process of child immigration to Canada was largely unchanged from 1868 to 1939 , the groups of children increased in both size and frequency. Nearly 100,000 children were brought to Canada from various organizations throughout this time period arriving on ships in groups of varying sizes. The children often had mixed feelings, excited about arriving in a new land, but at the same time experiencing sadness that they were leaving their birthplace. Overall, their arrival was important to the development of rural Canada, a truth demonstrated by the ever increasing demand for their services. A discussion of the beginning of the movement is essential to understand the significant role these juvenile immigrants played in Canada's history.

Initially, destitute children from Britain were housed in orphanages throughout the major towns and cities of England, Scotland, and Wales. Because there were so many poor, homeless, and orphaned children in Great Britain, these homes quickly became overcrowded, and alternatives were sought for the ever increasing number of children who required assistance. Although it had been over fifty years since Socket, Robinson, Bodkin, and Chambers had proposed sending children from the streets of Britain to the rural areas of Canada, by the 1860s, it seemed reasonable with the ever increasing child population, that their ideas actually be put into action. Moreover, the belief that children could not receive proper moral training in crowded cities and orphanages was gaining popularity through the actions of the reformers involved in the 
Evangelical Movement (this will be discussed later in further detail). Therefore, it was thought that sending children to Canada would benefit them by providing a sound moral upbringing, and would simultaneously reduce the negative influences of urban life. Additionally, the financial benefits of sending children to Canada were recognized. It cost about £12 per year to look after a child in an institution, but only a one time payment of $£ 15$ to send a child overseas. ${ }^{21}$ The numerous benefits that could be gained by sending children to Canada were recognized as of the late 1860s. It was at this time that the major period of juvenile immigration began, fuelled by the Evangelical Movement.

The Evangelical Movement began to flourish within Britain in the 1850s and 1860s as a reaction to the evident societal ills of the Industrial Revolution. This movement included Protestants, Methodists, and to a smaller extent, Baptists, who preached the gospel to anyone who would listen. The movement had a strong focus on the conversion of others to the Christian faith, as well as on activism, missionary work, and assisting the less fortunate. ${ }^{22}$ This was essential to the movement of British children to Canada, as various reformers each did their part to improve the lives of poor and destitute children in Britain. According to historian Marjorie Kohli, the Evangelical revival in Britain during the 1860s led to the formation of many religious humanitarian organizations. "Homes" were set up to teach children about God, to give them some food, and to make sure they had good moral teaching. Some homes became training centres for boys and girls where they could learn job skills. The goal of the training centres was to teach the children useful skills to help them secure meaningful employment, so that they

\footnotetext{
${ }^{21}$ Bean and Melville, Lost Children, 5.

${ }^{22}$ For further information on the Evangelical Movement in Britain, see: David William Bebbington, Evangelicalism in modern Britain : a history from the 1730s to the 1980s, (London: Unwin Hyman, 1989).

${ }^{23}$ Kohli, The Golden Bridge, 10
} 
would no longer have to resort to begging on the streets. Eventually these "homes" truly became the residences of many poor and destitute children through the influence of various philanthropists.

One of the earliest "child savers" was Maria Rye. Child savers were individuals who dedicated their lives to ensuring that poor and destitute children were taken off the streets and were given training and education. Many of these "child savers" became involved with the juvenile immigration movement. Rye herself was encouraged by the Archbishop of Canterbury and Lord Shaftesbury, other Evangelicals who also had the support of the government. She began her work in the Ragged Schools, a place where children and young adults of the working class could receive free schooling. Rye was most interested in helping the young women there escape the detrimental conditions they faced. ${ }^{24}$ She intended to do this through a system of training the women and then securing their emigration to various British colonies. She first began by placing women overseas, sending them to New Zealand, Australia, and finally Canada in 1867. She then followed this process by sending young children, mainly girls, to Canada to act as domestic workers. She believed that by doing this, they would fare better than if left in Britain. She justified her position:

What treatment will they receive from the cold, the starvation, the temptation they receive in our gutters; what justice will they receive from our hands when the police, the gaol, the hospital and the Magdalen receive them? Can anything I introduce them to in Canada or America be worse then that to which they are doomed if we leave them where they are now? ${ }^{25}$

Rye explained that the women she brought to Canada would have many more opportunities in the New World than in Britain. Joy Parr, a historian, describes the Evangelical viewpoint stating

\footnotetext{
${ }^{24}$ Kohli, The Golden Bridge, 71.

${ }^{25}$ Gillian Wagner, Children of the Empire (London: Weidenfeld \& Nicholson, 1982), 41-42.
} 
that this type of child emigration acted as a safety valve for internal disorder and a path to salvation of the immoral children. ${ }^{26}$

Maria Rye brought her first group of girls to Canada in 1868, and after touring Southern Ontario in 1869 , she decided to open a receiving home for girls in Niagara-on-the-Lake called "Our Western Home." This home was to house the young immigrant girls from her sailing parties until an appropriate placement was found for them. Unlike Dr. Thomas Barnardo, Annie Macpherson and other philanthropists of the time, many of Maria Rye's girls came from the workhouses and other training institutions in London rather than from the streets or orphanages. ${ }^{27}$ This tended to place her under greater scrutiny than her colleagues. Her lack of concern with regard to the treatment of children once they had left her care was publicized in 1874 through the Doyle report (discussed below) and the Board of Guardians in England ${ }^{28}$ Rye faced many additional criticisms, including accusations that she improperly screened the host families, and that a large percentage of her girls were misbehaving and were being returned to the home or to England. According to historian Kenneth Bagnell, five of every one hundred children Rye brought to Canada returned to England, and the average stay of one of her children in an employer's home was only thirty days. ${ }^{29}$ Furthermore, it was demonstrated that Rye received monetary bonuses for bringing children to Canada while other philanthropists did not. She made approximately $\$ 12$ for each child she brought overseas, and thus clearly had at least some mercenary motivation for her work. ${ }^{30}$ Regardless, Rye's program helped set the precedent

\footnotetext{
${ }^{26}$ Parr, Labouring Children, 27.

${ }^{27}$ Kohli, The Golden Bridge, 73.

${ }^{28}$ Ibid., 76-79. Various discrepancies in Rye's work are described through letters received by the Board of Guardians and through Andrew Doyle's report in 1874. These criticisms subsequently led to Maria Rye suspending her child migration scheme for 1875 and 1876, and the entire system being reviewed in 1878 .

${ }^{29}$ Bagnell, The Little Immigrants, 34.

${ }^{30}$ Ibid., 34.
} 
for child migration to Canada. Although she did not bring child immigrants to Canada until 1868 , by 1871 Rye was bringing over 450 children per year from a total of thirty-six Unions. This demonstrates how quickly the program of juvenile immigration became popular within Ontario. Overall, Rye brought almost 5000 children, mainly girls, to Canada. As such, although tainted with scandal, her impact on child immigration in the $19^{\text {th }}$ century was very significant. She was the first philanthropist to encourage migration of British children to benefit both Canada and the children themselves.

Annie Macpherson was another important philanthropist of the 1860s and 1870s who assisted both boys and girls in England, and brought many of these children to Canada. She was a born-again Christian who was interested in the Evangelical Movement from a young age, and made it her life's mission to help the poor in London's East End. ${ }^{31}$ The East End of London contained many factories and was home to much suffering from chronic poverty. Living conditions were poor and life expectancy was very short. Macpherson recognized this poverty and was especially struck by the young children forced to work in this area. Her first experience with these working children was in 1867 :

...Annie Macpherson entered a dark, smelly house and heard voices on an upper floor. She climbed the gloomy stairway and opened a hatch upon a sweltering attic. Inside was a sight that would move her to direct the rest of her life, not the miseries of poverty in general, but to the suffering of children. Everywhere in the attic...crouched more than thirty small girls, their arms as thin as broomsticks, at work making matchboxes.

"They were hired," Annie Macpherson said later, "by the woman who rented the room." Each child received three farthings, less than one penny, for making a gross of boxes, each gross requiring the child to handle two hundred and eightyeight pieces of wood. The girls, she estimated were mostly between the ages of eight and ten, though there were a few who were younger. On the table was a loaf

${ }^{31}$ Ibid., 23. 
of bread. When the children were so hungry they could not go on, they were given a slice. They paid for it our of their earnings. ${ }^{32}$

After witnessing this sight, and realizing this type of slave labour was likely occurring elsewhere, Macpherson published several articles and pamphlets about the conditions of the children in the East End, including a story called "The Little Matchbox Maker." After publishing this story, she used the acquired funds to assist the children, and encouraged others to help her remove children from the streets.

The publicity she received through her published works allowed Macpherson to open a small home for young boys under the age of ten. This was soon followed by a second home for young girls. Macpherson's third home in London was for boys aged 10 to 13 and provided a place to live and receive educational training in reading and writing. These boys also received the opportunity to learn job skills such as shoemaking, tailoring, and domestic duties. ${ }^{33}$ Annie Macpherson's influence was quickly spreading throughout London, and her homes were providing a better future for hundreds of needy children.

In 1865 Macpherson turned to R.C. Morgan, an entrepreneur and fellow philanthropist for help to raise more money to rent a home for children. With his assistance, she was able to raise enough money to rent 60 Commercial Street in the East End, and renovate the warehouse space to become her "Home of Industry." In this location, between 120 and 200 children worked at menial tasks to earn some money and develop job skills. They also received a bit of food and religious education. Eventually, the children not only worked at the Home of Industry, but lived there as well.

\footnotetext{
${ }^{32}$ Ibid., 24.

${ }^{33}$ Kohli, The Golden Bridge, 90.
} 
Although her various homes provided spaces for many poor and homeless children to live, it was clear that there were far too many poor children on the streets to be able to help them all. During the 1860 s it was estimated that there were over 30,000 destitute children in the East End of London. ${ }^{34}$ This number is astounding, and it demonstrates why emigration of children to Canada seemed such a viable option at that time. In the early months of 1869, Macpherson wrote another article to the people of London asking for monetary support for her plan to send both families and children to Canada to work on farms. In the summer of 1869 , she had raised enough money to be able to send 500 people to Canada as families, where both parents and children would work in rural areas. When she received word that they were successfully settled across Southern Ontario, Macpherson prepared a group of one hundred boys to go to Ontario to work as farm helpers.

Macpherson received a great deal of assistance in her emigration scheme as well as her resettling of children within Canada from two of her sisters, Louisa and Rachel. In the early months of her immigration plans, the town of Belleville presented Macpherson with a home which she could use for receiving and distributing the children she brought over until she found suitable residences for them. This home, called Marchmont, served as a point where she could keep an eye on the children and maintain contact with them after they were placed on farms throughout Ontario. After organizing Marchmont as a receiving home, Macpherson expanded her influence within Canada through the construction of two further receiving homes in 1872; one in Knowlton, Quebec and one in Galt, Ontario. She then expanded her work into Quebec and Southwestern Ontario, in order to place more children with appropriate families. The various

\footnotetext{
${ }^{34}$ Bagnell, The Little Immigrants, 26.
} 
homes Macpherson opened in both England and Canada were able to provide destitute children with a better chance at life. In conjunction with her two sisters and several smaller organizations, Annie Macpherson's program of juvenile immigration eventually brought over almost 14,000 children to Canada. ${ }^{35}$ Her influence was both positive and substantial over the years she cared for children throughout England and Canada.

Another influential philanthropist was William Quarrier, who was born in Scotland and did most of his child-saving work in that country. Having seen the staggering population increase within the major cities of Scotland, especially Glasgow, Quarrier was interested in helping homeless boys find valuable occupations. He had already heard of the work of both Thomas Barnardo and Annie Macpherson in London, and wanted to open up a similar type of homes where children would be able to gain educational and religious training in addition to having a place to live. ${ }^{36}$ In 1871 , Quarrier secured the funds for his project from a wealthy business man named Thomas Corbett, and quickly found an appropriate location. Although it was a small converted workshop, Quarrier decorated it with pages from the Bible and made the place seem like a real home for the boys who stayed there. ${ }^{37}$ By the end of 1872 , he had sold his shoemaking business to earn money in order to purchase another building for homeless girls. The two homes, as well as several more he opened with generous donations from the public, were successful in helping hundreds of children. However, Quarrier quickly realized that there were far more children to help than he could fit within the walls of his orphanages. Furthermore, he believed that there was a better system of care which could be provided to these destitute children.

\footnotetext{
${ }^{35}$ Report of G.B. Smart 1922-1923, Personal Papers of George Bogue Smart (hereafter stated as PPGBS), Record Group (hereafter stated as RG) 76 Immigration Series I-A-1, National Archives of Canada hereafter stated as NAC), Volume 170, Reel C-7327, File 54087 part 1.

${ }^{36}$ Magnusson, Quarriers Story, 32-33.

${ }^{37}$ Ibid., 35.
} 
Quarrier's unique method of housing children sets him apart from other reformers of the same time period. He proposed a "village" system of care for children rather than large orphanages:

...I would like to see an Orphanage established near Glasgow on the cottage principle, to which children from any part of the country could be sent. By the cottage principle, I mean a number of cottages built near each other, say ten, each capable of accommodating twenty to thirty children, with a father and a mother at the head of each household; playground and other appliances attached to each cottage, with a schoolhouse in the centre; also a central workshop; the father of each family to be able to teach a different trade...the mother to do the cooking for each household, with assistance if needed....It is desirable to keep up the family and home feeling amongst the children, and we believe this cannot be done in large institutions where hundreds of children are ruled by the stringent uniformity necessary where large numbers are gathered together for years. ${ }^{38}$

This type of housing for destitute children would enable them to receive all the comforts of home. Having "parents" who would supervise the children in smaller groups would make the atmosphere friendlier, and less institutional. The children would receive schooling, job training, and have Christian values taught to them, which would give them many more skills to succeed than those children who were simply placed in large institutional orphanages.

Quarrier started building his cottage home in the village of Bridge of Weir, sixteen miles from the centre of Glasgow, in $1876 .{ }^{39} \mathrm{He}$ began with a central building and several cottages and sent the children offsite for schooling. By the late 1890s, the village was a sprawling community of 52 buildings housing over 900 children. ${ }^{40}$ This type of village community was incredibly successful for Quarrier and emphasized his position as a caring and innovative philanthropist. Although the Quarrier cottage homes were more than successful at taking many poor and

\footnotetext{
${ }^{38}$ Ibid., 37.

${ }^{39}$ Ibid., 42.

${ }^{40}$ Ibid., 63.
} 
destitute children off the streets, it was clear that many children needed opportunities that could not be provided by keeping them in the homes in Glasgow and Bridge of Weir. Therefore, Quarrier collaborated with Annie Macpherson and others to be able to send some of his children to Canada. He believed that emigration would help the children that he had rescued from the streets of Glasgow:

By the emigration feature of the work we are enabled to place these children in Christian homes in Canada, where they will be kindly cared for and watched over by Miss Macpherson and her helpers. By this means we hope to be enabled yearly to rescue a fresh set of boys and girls, whilst, without this provincial outlet, we should be stocked up with the same set of children for four or five years, and unable to rescue more. And to those who object to emigration as withdrawing labour from this country, we would say, 'Come and see the children as we take them in, and you will perceive that not only the labour market, but the crime market, is likely to be affected by our work of rescue. ${ }^{41}$

Essentially, Quarrier believed that he would be doing a service to both Canada and Scotland by allowing his rescued children to come to Canada to live and work. He believed that by sending children to Canada, where they would be well taken care of, that he would actually be able to help more children, since the those who were sent would open up needed spaces in the Glasgow orphanages that he ran. This resulted in many children moving through the system more quickly by emigrating to Canada. Furthermore, Quarrier believed that by taking more children off the streets of Scotland into his home and teaching them proper morals, the nation would benefit through a lower crime rate. Canada would further benefit from these Scottish orphans as helpers on farms and in rural homes.

Quarrier began sending children to Canada in 1872 with a small group of sixty sent in the custody of Annie Macpherson. For several years Quarrier continued to send small groups of approximately sixty children to Canada. His groups increased in size steadily between 1879 and

${ }^{41}$ Kohli, The Golden Bridge, 170. 
1887 , sending over 2000 children during that time period. ${ }^{42}$ It was in 1888 , after sending over more children than just Macpherson could handle, that Quarrier acquired his own receiving home called Fairknowe in Brockville, Ontario. Great strides were taken to keep tabs on the children at their placements within Canada, although this was sometimes difficult since the children resided throughout Southern Ontario and into Quebec. ${ }^{43}$ The training they received prepared them well. Alexander Burgess, the visitor of home children for Quarrier stated that over 95 per cent of children "did well," very few were troublesome or unsuitable, and only a very small percentage ran off. ${ }^{44}$ Overall, until Quarrier stopped sending children to Canada in the early 1920 s over 7,000 of his rescued children found new lives in Canada.

Another reformer from the Evangelical Movement who deserves recognition for his work bringing British children to Canada is Dr. Thomas Barnardo. He is perhaps the best known of all reformers as his organization to care for neglected children in Great Britain began in the 1870s, is still in existence today. In the late $19^{\text {th }}$ and early $20^{\text {th }}$ centuries, his work with children in England and Canada was exceptional and resulted in nearly half of the 100,000 total of British child immigrants.

Barnardo realized his life's ambition at an early age after being converted to Brethrenism, a Christian sect, at the age of only seventeen. He believed that it was his mission in life to help sick and poor children, and he took it upon himself to encourage others to do the same. Until he was twenty years old, he preached in his hometown, encouraging men to find God and Salvation and to help others. In 1866, his life was profoundly changed by a man named Hudson Taylor,

\footnotetext{
${ }^{42}$ Magnusson, Quarriers Story, 74.

${ }^{43}$ Ibid., 74.

${ }^{44}$ Ibid., 74.
} 
who encouraged him to go to China and become a missionary because "a million a month [were] dying in China without knowing Christ. ${ }^{, 45}$ Barnardo traveled to London in the hope that he would be accepted as a missionary by the China Inland Mission. According to social historian Gillian Wagner, after being in London only several months Barnardo witnessed a large cholera outbreak sweep through the East End of London, killing over a thousand people, and plunging many into economic and physical turmoil. This epidemic was what opened his eyes, more than anything else, to the miseries faced by the poor. ${ }^{46}$ Barnardo decided that both in order to become a missionary to China and to be able to help the poor of London, he would need further training.

In late 1866, Barnardo became a medical student at the London hospital. Although he was intelligent and dedicated, it was obvious that Barnardo was not suited to either medical or missionary work. Kenneth Bagnell argues that Barnardo's personality was too self-centred and authoritarian, and his religious attitude was so deeply influenced by Brethrenism that he was unable to submit to the direction of others. ${ }^{47}$ Although he never completed his medical degree, Barnardo was known as Dr. Barnardo throughout his lifetime.

The story of how Barnardo first became involved in child saving is somewhat of a folk tale, but is important to understand how passionately he felt about his work, and how quickly it expanded. According to various historians, Barnardo was walking home from the London Hospital one night in the winter of 1869-70 when he came across a young boy, Jim Jarvis, who

\footnotetext{
${ }^{45}$ Bagnell, The Little Immigrants, 89.

${ }^{46}$ Wagner, Barnardo, 18-19.

${ }^{47}$ Bagnell, The Little Immigrants, 90.
} 
was orphaned and was sleeping on the streets. ${ }^{48}$ After asking him where he lived and where his mother was, Jarvis told him that he had no home and his mother was dead. Barnardo proceeded to ask the boy if there were others like him living on the streets, and received the troubling answer that there were many more children without homes or parents. After being led to where the boys were located, the vision stuck in his mind for many years and influenced his future:

That awful night of discovery...was not forgotten, for again and again the faces of those boys, their destitution and their mute appeal for help entered into our soul until, leaving ourselves and our future career in the hands of Him who ruleth all men's hearts, we were enabled to renounce a life of usefulness in another and distant land. ${ }^{49}$

After seeing the misery in his own country, Barnardo was forced to re-evaluate his choices. When he was unable to stop thinking about the poor orphaned children, he finally gave up his dream of becoming a missionary in China, and instead set out to care for the children of England.

In 1870 Barnardo set up his first home for destitute boys called Stepney Causeway in East London. Like Annie Macpherson, Barnardo received monetary assistance from his friend R.C. Morgan to open up his first home. ${ }^{50} \mathrm{He}$ chose a large, inexpensive house that he renovated to make room for seventy boys who were fed, cared for, and given a basic education. They received all of this in exchange for following a strict schedule of study, rules, and discipline. The boys were also required to perform household tasks, such as making the beds, baking, cleaning,

\footnotetext{
${ }^{48}$ Kenneth Bagnell, Gillian Wagner, and Gail Corbett all recount the story of Jim Jarvis in their published works. This story, published by Barnardo in The Christian newspaper in 1872 is reported to be true, but doubt has been cast upon the validity of the story in recent years. Considering that Barnardo had already been in London for three years, he should have been quite familiar with the street children, and their plight. Although it may or may not be a true account, this tale demonstrates the dramatic flair with which Thomas Barnardo lived his life and explained his reasoning for helping children. No matter what the truths of his beginnings into child saving are, it is clear that he was successful at helping many children throughout his life and beyond.

${ }^{49}$ Bagnell, The Little Immigrants, 93.

${ }^{50}$ Wagner, Barnardo, 36.
} 
and scrubbing. ${ }^{51}$ They also spent half their day in a trade school where they learned skills that would be useful later in life such as tailoring, shoe repair, and bread making. The money the boys earned through these tasks was used to further the programs initiated by Barnardo, and to offset the costs of running the home. ${ }^{52}$

Barnardo quickly gained a reputation for himself among the people in London working with the poor. Helping poor and destitute children was the most important work to him, and he used whatever means necessary to achieve his goals. Gillian Wagner writes of how he was different from other Evangelical child savers:

His unambiguous appeals for money to expand his work had distanced him to an extent from his more orthodox Evangelical co-workers, who preferred to wait upon God and trust to the slower workings of the Evangelical grapevine to meet their needs. He was discovering and using his literary gifts to stir the consciences of his readers, and since 1869 he had been selling photographs of the children he had rescued in an attempt to raise money for his growing enterprises. Packets of photographs were advertised for sale which must make him one of the first, if not the first to use this medium for both fund-raising and publicity purposes. ${ }^{53}$

His ambitions and methodology set him apart from other child rescuers, and perhaps this is what made him more successful. By advertising the plight of children in need, Barnardo was able to raise more money than others in his field and was ultimately able to help more children. Despite the fact that his personality suggested vanity and the desire for fame, it was clear that he was undoubtedly concerned about the spiritual and physical welfare of the children he helped. ${ }^{54}$ Although it was the Evangelical way to depend on the kindness of others for donations, Barnardo decided it would be more effective and beneficial to the children if he were to promote his cause

\footnotetext{
${ }^{51}$ Bagnell, The Little Immigrants, 98.

52 Ibid., 98.

53 Wagner, Barnardo, 52.

${ }^{54}$ Shirley E. Boyle, "An analysis of the Social Mores of Canadians 1869-1924 as demonstrated in their Treatment of the Home Children," (MA research essay, Carleton University, 1997), 30.
} 
rather than simply waiting for the money to come in. His greatest legacy, according to historian Shirley Boyle, was that he created an awareness of the desperate situation of working-class families as a result of the Industrial Revolution amongst the parliamentarians and the middle and upper-class public. ${ }^{55}$

Due to his success obtaining donations and benefactors, Barnardo was able to open several more homes for destitute boys and girls. After Stepney Causeway, the Girls Village Home was constructed in 1875 . This was similar to Quarrier's village, where there were numerous cottages, "mothers," a school for the girls to attend, a church, and other administrative buildings. ${ }^{56}$ In 1879, Barnardo received Teighmore House as a donation so he could have a home for younger boys, and in 1881 a Labour House for young men and a young women's hostel were opened. His work became even more respected with the opening of the Babies Castle in 1884, as there was an ever increasing number of abandoned and destitute infants in the London area. Yet much like the other philanthropic organizations, the Barnardo homes soon became overcrowded. In order to attempt to help a greater number of children, Barnardo also became involved in the program of juvenile immigration.

Having seen the initial successes of Maria Rye and Annie Macpherson, Barnardo sent his first group of boys to Canada with Macpherson in the early 1870s. After learning of the success of his boys on Canadian farms, each year, he enlarged the groups of children he sent with Annie Macpherson. Eventually, in 1882, he decided to launch his own program to send larger and more

\footnotetext{
${ }^{55}$ Ibid., 30-31

${ }^{56}$ Corbett, Nation Builders, 16-17.
} 
frequent groups of children to Canada. By this time, he was completely convinced that child emigration to Canada was the best way to help the greatest number of children:

Well-planned and wisely conducted child emigration especially to Canada, contains within its bosom the truest solution of some of the mother country's most perplexing problems, and the supply of our Colonies' most urgent needs...First, it relieves the over-crowded centres of city life and the congested labour markets. Second, it supplies what the colonies are most in want of, an increase of the English speaking population. Third, it confers upon the children themselves unspeakable blessings. The change at the young and formative period of their lives gives to each child whose character is good, and who is successfully absorbed into the colonial population, such an immediate prospect of an independent existence upon a higher plain as hardly could have been imagined within its reach. ${ }^{57}$

Barnardo was in agreement with many other reformers that children would be able to achieve more by leaving the crowded slums of Britain's major cities, and coming to the "wholesome goodness" of Canada's rural areas. Since Barnardo believed so strongly in the scheme of immigration, and he achieved a well-earned reputation for providing excellent care to children, he was able to bring over 30,000 children to Canada through his organization between 1882 and 1939.

Within Ontario, Barnardo set up two major receiving homes, one for boys in Toronto, and one for girls, Hazelbrae, in Peterborough. These homes were the central points to which Barnardo children were sent. His system of juvenile and child immigration was unique in that he had many representatives who provided aftercare to the children. A bank account was set up for the children to hold their earned wages until they reached what was considered adult age (18 for boys and 21 for girls), and they could make a withdrawal. This ensured the children would not spend their money frivolously when on the farm or in town and that the Barnardo organization could intervene for any child who was not receiving their proper payments.

\footnotetext{
${ }^{57}$ Ibid., 26.
} 
Visitation and correspondence between the children and the Barnardo homes was also a very important part of the organization, as Barnardo himself was able to gain personal insight into how the children's lives were once in Canada. He also gave out solid silver medals to boys only for their excellent service and representation of the home.

Occasionally, negative comments were made about Barnardo. His critics accused him of "philanthropic abduction," whereby he shipped the children to Canada without their parents' permission. According to a home child study by Joy Parr, six percent of boys and eight percent of girls came to Canada illegally, without parental consent. ${ }^{58}$ This caused a great deal of debate within Britain, and Barnardo was both challenged and taken to court on several occasions over this matter. He defended himself and his methods by stating that he was doing what was in the children's best interest, and that they would eventually be better off in Canada. He did not care that occasionally he was breaking the law. ${ }^{59}$ Even when Barnardo confessed his wrongdoings, and stated he would willingly take responsibility for his activities, the British government did not take action against him. ${ }^{60}$ Barnardo was a caring man and a great philanthropist who believed that the betterment of children's lives was of the utmost importance. Due to his actions, and subsequent court cases, the British homes were given greater privileges to determine what was best for the child. By placing their child in the homes, parents or guardians were obligated to give consent for their child to emigrate. ${ }^{61}$ This ensured that Barnardo was able to take children out of negative situations in London and bring them to Canada as he saw fit. In this way he

\footnotetext{
${ }^{58}$ Parr, Labouring Children, 67.

${ }^{59}$ Various legal proceedings that Thomas Barnardo found himself in can be found in Joy Parr's Labouring Children on pages 67-72.

${ }^{60}$ Wagner, Barnardo, 207-208.

${ }^{61}$ Parr, Labouring Children, 71.
} 
helped to greatly improve the lives of over one third of the approximately 100,000 children who came to Canada as part of the major juvenile immigration movement.

Although the idea of transporting children from Britain to its colonies was not new, the overall combination of the Evangelical Movement, child savers, and the receiving home system demonstrated the innovative nature of juvenile immigration to Canada. Despite the complaints of British and Canadian citizens, it is clear that the reformers believed they were doing a great favour to the children. By bringing the children to Canada, it was believed they would be able to live a long and healthy life compared to the one destined for them in Britain. The only challenge to the process was the actual transportation of the children across the Atlantic Ocean. This was an endeavour which required coordination on the part of the philanthropists and shipping lines, and eventually became a routine practice. 


\section{Transportation and Settlement}

It is important to examine the actual process of sending children to Canada. Significant changes occurred within the immigration process and the care of home children over time. These changes often corresponded to changes in social values within Britain and Canada. Initially the children were unceremoniously shipped to Canada to become farm workers because there were too many children in Britain and not enough in Canada. At this time, they were looked upon as beings who needed discipline and routine to become productive adults. They were unable to receive this in Britain on the streets, and therefore philanthropists and the general public believed that the children would have a better chance at success in Canada. These individuals were not concerned with the various emotional issues that the children faced being separated from friends, remaining family members, and the only home they had ever known. Therefore, sending children to Canada truly reflected the beliefs of the time period. Initially, it was assumed that the children were emotionally resilient and would fit in fine. However, over time this attitude changed, and consequently so did the methods of transportation and aftercare to suit the needs of the changing child, and to satisfy the concerns of child welfare reformers.

The process of sending juvenile immigrants to Canada was quite straightforward in that each child was sent upon a ship with a party of other children and one or more adult supervisors. Various homes had different preparations that they made before the child was to board a ship and sail to Canada. Many of the smaller homes even prepared their children in the way that one of the larger organizations would set out for them. This was because many of the smaller organizations sent their children with the major reformers of the time period including Maria Rye, Annie Macpherson, or Thomas Barnardo. 
The major preparations of any agency were a variation on the following process. First, a group of children was assembled to come to Canada. Sometimes children volunteered to come to Canada as they believed it would be an adventure, or a chance at a better life than remaining in the orphanage. At other times, the children who were travelling overseas were told just weeks or days before the voyage that they were leaving for another country. The groups of children could be a combination of boys and girls, or could be just one gender. Most often, the groups were composed of a combination of children from multiple locations of one organization's homes. However, for the smaller organizations, they often assembled small groups and sent them with a large group from another organization. Once the group of approximately 200 to 400 children had been assembled, preparations were made to pack a specific set of travelling items inside a trunk to bring to Canada. This included items of clothing, both winter and summer, boots and shoes, stockings, overalls for farm work, toiletry items, and often a Bible and hymn book for their religious benefit. ${ }^{62}$ Once completely assembled, the children travelled from their various homes to a larger home near the shipyards and were given a thorough medical examination before boarding the ship to Canada. If they had any health problems, be they physical or mental, the child was held back either temporarily or permanently, depending on the condition.

Once the children were on board the ship, the voyage could last anywhere from six days to two weeks. The quarters were often cramped, the food bad, and seasickness was widespread. Also, since there were so many children, and so few supervisors, the children often got into trouble. Florence Aulph recalled that on her voyage to Canada, the children were playing around the rails of the ship, and one boy was pinned and killed by a wave that came over the side of the

${ }^{62}$ Corbett, Nation Builders, 124. 
boat. ${ }^{63}$ Situations such as this were not very common, but did arise occasionally, and thus there was an element of risk on the journey over. The most common point of entry to Canada was Quebec, but ships sometimes docked at Halifax, Nova Scotia, or Saint John, New Brunswick. ${ }^{64}$ From here, the children boarded trains for their next destination.

After the juvenile immigrants arrived in Canada they were sent by train to a specific receiving home until a family was arranged to take them onto their farm. In Ontario there were several different receiving homes for British children to reside in which were run by the employees of the major philanthropic organizations. These homes were located in Brockville, Peterborough, Galt (now Cambridge), Belleville, and Niagara-on-the-Lake; areas where children could be sent most easily to the various regions of the Ontario countryside. Furthermore, they were in locations that were easily accessible by train. Considering that most of the ships bringing children to Canada docked at either Halifax or Quebec and most of the children went to farms in Ontario, the receiving homes needed to be located in areas where they could take the train into and out of the town. It was important that the homes be accessible for children who did not have a placement immediately upon coming to Canada, or for those who had a problem at the farm they were sent to. ${ }^{65}$ The receiving homes were essentially refuges where British children could stay with caretakers and children from their own country who understood the challenges that they faced in a new land.

\footnotetext{
${ }^{63}$ Bean and Melville, Lost Children, 10.

${ }^{64}$ Corbett, Nation Builders, 35.

${ }^{65}$ Kohli, The Golden Bridge, 107.
} 
It was an interesting process to find a family that would be appropriate for taking in a child from Britain to work as a farmhand. In fact, this process was often neglected or not taken seriously enough, and children were placed with farmers who did not treat them properly. In the case of Maria Rye's organization, advertisements were put out in farming newspapers, through the church, and through word of mouth in farming communities that she had children for hire. Although she drew up forms that stated the requirements of both the child and the farmer, and the terms of the indenture, the necessities were often ignored. According to historian Kenneth Bagnell, the terms of Rye's agreements stated that the child was to be bound until they were eighteen years old, and were to be fed, clothed and sent to Sunday school until they were fifteen years old. After they reached fifteen years of age, they were to be paid a wage of three dollars a month until reaching seventeen when they would receive a raise to four dollars a month. ${ }^{66}$ Although this agreement was well intended, it was often ignored when the realities of farm life set in. Many home children were not sent to school or paid for their services, and farmers often treated them as a worker rather than a child. This is why the juvenile immigrants often felt mistreated and lonely.

Annie Macpherson's process of finding appropriate families to take in the children from Britain was slightly different from the advertising method utilized by Rye but it still had its drawbacks. She accepted applications from interested individuals, and received a statement about their character from neighbours or the clergy. Although this is slightly more thoughtful than Rye's process, it is clear that a simple statement was not enough to go on when placing an innocent child in a vulnerable situation. The emotional needs of the child were rarely considered by either Rye or Macpherson, and the simplest method of placing as many children as possible

\footnotetext{
${ }^{66}$ Bagnell, The Little Immigrants, 35.
} 
was used. This explains why, in the early years, there were complaints of child mistreatment. William Quarrier also attempted to ensure the suitability of homes for the juvenile immigrants he brought to Canada. His process involved the home's superintendents talking to the applicant, interviewing the neighbours and asking questions about the farmer's background, and ensuring that each home practiced the Christian faith through testimony of the local minister. ${ }^{67}$ This process of interviewing multiple people ensured that more of Quarrier's children were placed with a good match immediately, and that the child could be successful in their new life.

Yet as mentioned, reality often differed greatly from the original arrangement. Once the child was on a farm in rural Ontario, they were subject to the farmer's rules regardless of what their contract had set out for them. This is why many individuals encouraged the homes to send individuals to visit juvenile immigrants in their place of employment. With inspections, it could be determined if the child was getting along well in their new home, and if they were being treated properly. Since these children were to be farm helpers and not slaves, they were to be treated in a manner befitting both a family member and a worker. This was often a hard balance for many of the employers to find. Some children were lucky and were immediately treated like one of the family, allowed to eat, sleep, and socialize with all members of the farm household. Other children were not as fortunate, and were forced to live, work, and eat separately from the family they lived with. The system that was intended by British philanthropists was one that fit more in the middle of these two extremes. It was assumed the child was being treated with respect and care by the host family, but it was also expected that the child take on many farming chores and jobs around the house. The family was not to be cruel to the child, but was to use them as they would use their own child or a hired farm worker. In many cases, the children were

\footnotetext{
${ }^{67}$ Magnusson, Quarriers Story, 72.
} 
expected to perform tasks that were beyond their physical means and those who did not obey their new "parents" were often beaten. For example, Joy Parr's study of over 900 Barnardo children indicated that 9 per cent of boys and 15 per cent of girls were subjected to excessive punishment. ${ }^{68}$ Gail Corbett also describes how some home children encountered various forms of maltreatment such as sexual assault, beatings, injuries with pitchforks, and impalements on fenceposts. Although this did not involve the majority of children, it was an unfortunate reality of the situation. ${ }^{69}$

As time progressed, concerns grew about the entire child immigration scheme both in Britain and in Canada. British individuals involved with child welfare issues were worried that there was too much neglect, abuse, and lack of concern for children once they were placed on a Canadian farm, while Canadians were concerned that the children were not fit for rural life. By 1874, children from Britain had been coming to Canada under the auspices of several different organizations for several years. It was at this time that the Local Government Board, which regularly inspected Poor Law facilities in Britain on a regular basis, decided that it needed to conduct an inspection of the children who were taken to Canada. ${ }^{70}$

Andrew Doyle, an inspector on behalf of the Poor Law in Britain, was chosen to investigate the conditions of home children in Canada, and was ordered to present his findings to the Government Board in Britain. He made his way through the Ontario countryside in 1874, stopping to see the receiving homes of Maria Rye and Annie Macpherson, as well as visiting over four hundred of their children who were placed with settlers in rural Ontario and Southern

\footnotetext{
${ }^{68}$ Parr, Labouring Children, 105.

${ }^{69}$ Corbett, Nation Builders, 58.

${ }^{70}$ Kohli, The Golden Bridge, 21.
} 
Quebec. ${ }^{71}$ Doyle released his report on the conditions of the home children in early 1875 . After merely three months of research, he came to the conclusion that the system had flaws, stating: “...to send them [home children] as emigrants can be regarded not as a way of improving their position, but simply of getting rid of them at a cheap rate...."72

Through his investigations, Doyle discovered that a system of aftercare for the children placed on Canadian farms was severely lacking. According to historians Philip Bean and Joy Melville, Doyle believed there were too many home children brought to Canada at one time, that the receiving homes were overcrowded, and that the philanthropists knew little about the families with whom they were placing children. ${ }^{73}$ Furthermore, Doyle discovered that there was a serious lack of supervision of children in Canada, especially in regard to the children brought over by Maria Rye. In England, the consistent inspection of placed children was a requirement, and could ensure that children were not mistreated or improperly paid, as some children in rural Ontario had complained. ${ }^{74}$ Kenneth Bagnell contends that Maria Rye was unconcerned about the children she sent out:

In the case of Miss Rye, there was actually no system of supervision at all; she simply gave out her children-throughout Nova Scotia, New Brunswick, and Ontario asking a few friends in each area to keep an eye open. She took the view that no news was good news. As a result, large numbers of Miss Rye's girls were never heard from again... ${ }^{75}$

Doyle found this practice disconcerting, especially since on several occasions when he attempted to find a child at a certain home, he was told that she was not there any longer and her

\footnotetext{
${ }^{71}$ Bagnell, The Little Immigrants, 39.

${ }_{72}^{72}$ Parr, Labouring Children, 32.

${ }^{73}$ Bean and Melville, Lost Children, 61-64.

${ }^{74}$ Kohli, The Golden Bridge, 23.

${ }^{75}$ Bagnell, The Little Immigrants, 43.
} 
whereabouts were unknown. ${ }^{76}$ Some of these young women travelled back to their homeland, while others moved towards the United States. Most disturbing however were the young girls who fled the home they were placed in to live on the streets of large cities, earning money to survive through prostitution. Many of these young women were not monitored after they left the home. Because of Rye's carelessness, Doyle was very harsh in his criticisms of her organization. He accused her of having careless policies, demonstrated that she did not have any system of supervision or inspection of her wards, and maintained she had not kept proper financial accounts. ${ }^{77}$ As a result of his report, Rye did not bring British children to Canada for several years, and she began a feud with Doyle that would last for many years. This report forced her to change her policies before she could bring additional children to Canada, while it also contributed to the increase in home child inspection.

Doyle's opinion differed on the practices of Annie Macpherson. Although she too had some shortcomings, he praised her in his reports. He wrote several times that the women involved in child emigration, especially Macpherson, accomplished a great deal that benefited the children, and were led by the highest morals. Doyle stated:

Of what these ladies have done and are endeavouring to do...for that class of children, it is impossible to speak too highly....The liberal and unostentatious was in which [Annie Macpherson] devotes the rare gifts with which she is endowed, the fulfillment of very onerous duties is beyond praise. ${ }^{78}$

Annie Macpherson was more careful than Maria Rye in that she maintained meticulous records and was very caring and involved with the children she brought over. Also, she did have a system of visitation set up whereby she had a hired man who travelled all over without any

\footnotetext{
${ }^{76}$ Ibid., 43.

${ }^{77}$ Kohli, The Golden Bridge, 78.

${ }^{78}$ Bagnell, The Little Immigrants, 41.
} 
financial restrictions to ensure he could reach as many children as possible. She also had several ladies who would make "friendly," unofficial visits to see the children in their day-to-day living situations. ${ }^{79}$ This system was already fairly good, but there were an ever increasing number of children who required visitation, and Macpherson's system of volunteers could not reach them all. She therefore took the suggestions from the Doyle report in an attempt to improve her system of child care.

Doyle's actions contributed to a greater awareness of the exploitation of children in Canada. Unfortunately, his many recommendations were not well-received in Britain or Canada because of the perceived advantages to both the sending and receiving countries, and the overwhelming support for the continuation of the child immigration program. ${ }^{80}$ Although many recommendations were ignored, Doyle's report did cause the number of child migrants to drop substantially in the year after his findings were presented while some new protection measures were put into place. However, the number of children quickly increased after these measures were implemented. Child immigration was becoming more popular and necessary as Canada was growing as a nation, and Britain's population and colonial power was increasing. It is interesting to note how the governmental policies and feelings of the public changed over time as both nations grew and changed. This is a reflection of the wider society of the late $19^{\text {th }}$ century. The reform movement was taking hold, and individuals were no longer satisfied with the way things were always done. Government and businesses were beginning to take a more active role in society's affairs, while more workers were still needed for the increasing job market. Juveniles were the right age, race, and character to take these positions within Canada.

\footnotetext{
${ }^{79}$ Kohli, The Golden Bridge, 24.

${ }^{80}$ Ninette Kelley and Michael Trebilcock, The Making of the Mosaic, A History of Canadian Immigration Policy (Toronto: University of Toronto Press, 1998), 91.
} 


\section{Reform Movement and Treatment of Home Children}

As British juvenile immigrants took on jobs within rural Canada, the reform movement led to many changes in society. This social development in Canada between 1868 and 1939 impacted the way Canadians acted towards these new immigrants, and how they were treated in their places of employment. This treatment of home children, when discussed in historical sources, has often been biased. These accounts most often have examined the maltreatment of the child immigrants and the negative effects they experienced on the farms of Canada rather than the positive benefits of the program. It is therefore essential that their treatment be considered in the social context of the time period. It is only natural that changes occurred in the seventy year period that children came to Canada as juvenile immigrants. These changes in opinion can be traced through how all children were treated, not just how home children were regarded. Overall, the care of home children reflected the changing society and the developments in raising children.

There was a strong belief in the first half of the $19^{\text {th }}$ century that individuals would be most successful if they worked hard and were self-sufficient. ${ }^{81}$ During the early years after Confederation, there was also an increase in schooling for children. More children were sent to local schools, and the accessibility of schooling for all children was emphasized. At this time of great change, it was also important that schooling be extended as a method of social control. Many school promoters believed that the working world or the community at large was a dangerous place for children and that they would be better off in the protective environment of

\footnotetext{
${ }^{81}$ Andrew Jones and Leonard Rutman, In the Children's Aid: J.J. Kelso and Child Welfare in Ontario (Toronto: University of Toronto Press, 1981), 16.
} 
the school. ${ }^{82}$ At the same time, as industrialization increased in the 1870 s and 1880 s, more individuals moved to urban areas such as Toronto. The number of poor in these areas subsequently increased as they did fifty years earlier in British cities. At that time, the demand for labour in the cities was high, and people began to move out of rural areas. As the urban population increased, an awareness of the conditions of the poor came to light as well.

Although the population of Ontario was becoming more sensitive to the needs of the working class, there were occasionally times when specific groups acted negatively towards the juvenile immigrants who came from Britain. In the 1880s and again in the 1920s, there were questions raised by the public as to whether or not the juvenile immigration movement was needed. Groups such as trade unions and child welfare societies often complained about the program for different reasons.

In 1874, complaints about the program from British reformers led to Andrew Doyle's investigation and subsequent report on the conditions of the home children. After this report was made public, a Select Committee on Immigration and Colonization was formed in Britain in 1875. This committee ordered the inspection of all Union children each year until they reached the age of eighteen. These inspections were initially conducted by paid agents of the homes and were sporadic, but in 1899 legislation was passed to form a new governmental position to deal specifically with British immigrant children. On January $1^{\text {st }}, 1900$, George Bogue Smart became the Inspector of British Immigrant Children and Receiving Homes, a position that he alone held until 1933. This standardization of inspection throughout Canada, and the publishing of yearly

\footnotetext{
${ }^{82}$ Alison Prentice, The School Promoters: Education and Social Class in Mid-nineteenth Century Upper Canada (Toronto: McClelland and Stewart Limited, 1977), 20.
} 
reports on the findings were important to inform the public about the state of the child immigration movement. These reports also acted to reassure people that treatment of the home children was improving as society became more concerned with the well-being of children.

The British juvenile immigration movement was not to last indefinitely, and changes in society which led to its dissolution began in the early 1920s. Firstly, with the Empire Settlement Act came new age restrictions on juvenile immigrants. This meant that after 1925, no children under fourteen would be admitted to Canada unless they emigrated with their family. Although this could have stemmed the flow of child immigrants, the numbers remained high into the 1930s, due to the high demand for labour. After the Depression began and economic changes occurred in Canada and throughout the world in the early 1930s, the movement of children from Britain to Canada began to slow. It continued to slow with the increase in xenophobia within Canada, and the movement eventually stopped altogether with the advent of the Second World War.

Within the timeline of social development described above, a major social change that occurred in Canada and was first initiated in Ontario was the advancement of schooling for children. The growing focus on compulsory education for all children, including home children, was such an important change that it is essential to examine when discussing the treatment of home children. As of 1871, attendance in publicly funded schools was mandatory for children between the ages of seven and twelve for a minimum of four months per year. By 1897, the 
schooling requirements for Ontario's children increased to ensure children went to school for at least five months per year until they were fourteen years of age. ${ }^{83}$

Ontario was the first province to pass this legislation and other provinces quickly followed. ${ }^{84}$ Between the years of 1851 and 1871 , the idea of schooling for all children began to be more widely accepted in Ontario. This can be clearly shown by the numbers of children who were enrolled in the common school. In 1851 there were just over 150,000 children enrolled, while only twenty years later over 400,000 children were enrolled in Ontario's schools. Although numerous children were enrolled in schools, many of these students were still not attending for the four months a year required by the government. Before the turn of the century, many families simply could not afford to lose the labour required of their children on a consistent basis. ${ }^{85}$

Schooling of the home children was a contentious issue as many of the employers believed that although the children were required to attend school until they were twelve (or fourteen as of 1897), the children had come to work, and that was what they were to do. In some cases, the host families kept their apprentices at home in the spring, summer, and fall months to help with the major chores on the farm. If they were sent to school at all it was often during the slower winter months.

Before the turn of the century, many of the British agencies were already stressing the advantages of free schooling in Canada, stating that the advancement opportunities for

\footnotetext{
${ }^{83}$ Parr, Labouring Children, 109.

${ }^{84}$ Paul Axelrod, The Promise of Schooling: Education in Canada, 1800-1914 (Toronto: University of Toronto Press, 1997), 37.

${ }^{85}$ Ian E. Davey, "The Rhythm of Work and the Rhythm of School," in Histories of Canadian Children and Youth, eds. Joy Parr and Nancy Janovicek (Toronto: Oxford University Press, 2003), 110.
} 
immigrants were numerous. ${ }^{86}$ In 1897 , legislation was passed in Ontario to protect British immigrant children, giving them the right to a public education. However, there were no penalties given to employers who denied them the opportunity. ${ }^{87}$ Further steps were taken by various organizations to give home children the benefit of a proper education. In 1895, Barnardo emphasized the value of his boys receiving a Canadian education in the winter months when they were not busy on the farm, and by 1907, every home child contract specified how many years the child was to attend school for at least four months per year. ${ }^{88}$ This was published in a pamphlet put out by the Barnardo's organization in Canada which stated the following:

Any person taking a boy will be required to sign an undertaking, in duplicate, at the time the boy is sent, engaging to provide for his maintenance and education, to send him regularly to Church and Sunday School, and to communicate periodically with the Agent of the Home, and otherwise to care for and to promote the boy's interests. ${ }^{89}$

Unfortunately, even with all of the requirements in place for home child education, many children did not receive the education they deserved. Joy Parr also describes the number of home children who received schooling:

Two-thirds of Barnardo's children aged 9 or younger when they came to Canada received regular schooling, but three-quarters of his emigrants aged 10 to 12 attended irregularly or not at all, and about the same proportion of arrivals aged 13 to 14 never saw the inside of a Canadian schoolroom. ${ }^{90}$

This may seem like many home children did not receive the education they were entitled to, however this does not differ much from Ontario-born children. Those children who were young when they arrived were often sent to school with their Canadian-born peers. Those who were nearly school leaving age and had already received some type of education in Britain were often

\footnotetext{
${ }^{86}$ Parr, Labouring Children, 108.

${ }^{87}$ Ibid., 110.

88 Ibid., 109.

${ }^{89}$ Bean and Melville, Lost Children, 40.

${ }^{90}$ Parr, Labouring Children, 109.
} 
kept out of school to work. Although the lack of education for home children in comparison to other groups has been discussed in other historical sources, it is clear that the educational practices of the late $19^{\text {th }}$ and early $20^{\text {th }}$ century were nearly the same for Canadian born children as they were for home children. This reflected the social beliefs of the time that children were still needed for their services within the home.

By the 1890s it was clear that child immigration was a popular and necessary practice. The rural population was in decline, as young men and women left the countryside; therefore there was a constant need for child immigrants to replace these individuals. The rural population of Canada declined from being $80 \%$ rural in 1871 to being only $50 \%$ rural in $1924 . .^{91}$ This was felt most acutely in Ontario where many people were moving to large cities and towns such as Toronto. It was in the $20^{\text {th }}$ century that the character of the child immigration movement changed from one with an Evangelical foundation to one that was more secular. In this transition the movement shifted to a focus on removing children from destitute situations condemned as "unhealthy" rather than "immoral."92 This demonstrated the decreasing emphasis on "saving" children from the British slums for religion reasons. There was a new focus on sending children to Canada for an improvement in their physical and mental well-being rather than for spiritual enlightenment. In the early 1900 s, Britain was also sending children to the colony of Canada as an imperial interest. The British government, as well as the philanthropists involved in the juvenile immigration movement, believed that the British race could be spread through rural Canada as a nation building project. ${ }^{93}$

\footnotetext{
${ }^{91}$ Ibid., 86.

92 Ibid., 142.

${ }^{93}$ Ibid., 143.
} 
Within Canada itself, individuals were becoming more concerned about the developmental needs of children. Historian Neil Sutherland argues that there were broad changes occurring in the Canadian way of thinking due to modernization and industrialization which contributed to the national transformation of childhood-related beliefs. ${ }^{94}$ By the end of the $19^{\text {th }}$ century, reformers were urging Canadians to change their methods of raising children. In the 1870s and 1880s, many Canadians demonstrated little awareness of children as individual people, and thus did not realize that children had an "emotional life." $"$ "At this time, all children were treated harshly, not just the home children. It was believed that children needed discipline in order to become productive members of society.

The reform movement began in the 1890s in Canada and was linked to similar progressive movements throughout the United States and the United Kingdom. This reform movement was led by middle class men and women in new professions that catered to children such as teaching, nursing, and medicine. ${ }^{96}$ They professed new ideas that changed the nature of how children were thought of in society, and this impacted upon the home children. The role of families and mothers were enhanced with the new beliefs, and there was a new belief that children needed tending and nurturing. ${ }^{97}$ Furthermore, because of these changes in the notion of childhood, "Canadians showed more awareness and understanding of the problems faced by boys and girls who were taken so casually from Britain to Canada..." ${ }^{\text {98 }}$ Becoming more aware of

\footnotetext{
${ }^{94}$ Neil Sutherland, Children in English Canadian Society, Framing the Twentieth-Century Consensus (Toronto: University of Toronto Press, 1976), ix.

95 Ibid., 6.

${ }^{96}$ Ibid., 14-15.

97 Jones and Rutman, In the Children's Aid, 26.

${ }^{98}$ Sutherland, Children in English Canadian Society, 29-30.
} 
the new practices of child rearing allowed Canadians to better appreciate the value that home children played in Canadian society, and the care they required when in a new situation.

Individual accounts of home children in Ontario before the reform movement show that conditions for children were difficult at times. For example, Katie Wallace, who arrived in Ontario in 1889 from a Quarrier home was sent to a family who did not treat her kindly. Her niece remembers: "My Aunt Katie...vomited in her bed. For this she was put in solitary confinement in the cold for three days, then brought out and severely whipped. ${ }^{\prime 99}$ Emma Kennett, who immigrated to Canada in 1878 and went to a farm in Port Hope, Ontario, was mistreated by the family with whom she was placed. Her daughter recalled that Emma was very unhappy with the family she lived with as they believed in taking more than their "pound of flesh" and on several occasions they refused to pay her the wages she was owed. ${ }^{100}$ Another home child, Robert Bishop, who was sent to St. Catharines, Ontario, also experienced abuse at the hands of his employer. He stated: "I am sorry to say I was abused. All this man cared about was the $\$ 5.00$ a month that he was paid by the home and all the work he could get out of me."101 According to Scottish historian Anna Magnusson, the children sent from Great Britain were very vulnerable and completely at the mercy of the families with whom they were sent to live. They relied completely upon the distribution homes in Ontario and Quebec to find them a good home in Canada, and this was not always the case. ${ }^{102}$ When one considers that there was not a comprehensive system of inspection set up until the $20^{\text {th }}$ century, the lack of concern for home children in the early years of the program is saddening.

\footnotetext{
${ }^{99}$ Magnusson, Quarriers Story, 96.

${ }^{100}$ Phyllis Harrison, ed, The Home Children (Manitoba: Watson and Dwyer Publishing Ltd., 1979), 13.

${ }^{101}$ Ibid., 20.

${ }^{102}$ Magnusson, Quarriers Story, 96.
} 
The improper supervision of home children in Canada led to some being poorly treated. However, there were families who ensured the children were well treated even before the advent of the child welfare system. Emily Boys, who came with Maria Rye's fourth party of girls in 1871, was taken in by a Mennonite family who treated her well, and taught her to cook, clean, and mind children. ${ }^{103}$ Agnes Short, who arrived in Ottawa, in 1880, was very fond of the family who took her in as they were very good to her, while Elizabeth Owen remembered a wonderful home in Canada where she was sent to church. ${ }^{104}$ Other stories of kindness prior to the change in the notion of childhood certainly exist, which demonstrates that home children were generally viewed in the same manner as other children of the time. Some were treated well and others were not; it really depended on the family in which one was raised. There also did not appear to be any differences in treatment based upon the gender of the child. Some families believed in harsher discipline than others, but nearly all believed that child rearing was something to be kept private and within the home. This could be why the Homes were reluctant to send inspectors to visit the children on a regular basis before the reform movement and why mistreatment occurred with the home children at this time.

With this newfound interest in helping to ensure that the needs of newcomer children were taken care of, various individuals came forth to take responsibility for child welfare. According to Andrew Jones and Leonard Rutman, the government and the public were becoming more involved in social welfare just twenty years after Confederation, which led to the formation

\footnotetext{
${ }^{103}$ Harrison, The Home Children, 11-12

${ }^{104}$ Ibid., 17, 25.
} 
of government-run and private charitable organizations. ${ }^{105}$ It was in the 1893 that the Children's Aid Society was formed. J.J. Kelso was an important figure associated with each of these changes in Canadian society. He worked very hard to instate measures within Ontario to protect children, including the home children. According to Patricia Rooke and R.L. Schnell, "the passage of the Children's Protection Act in 1893 provided a focus for action regarding juvenile immigration. ${ }^{106}$ A conference on Child Saving was held in 1895 to discuss the further protection of home children and the Act to Regulate Immigration into Ontario of Certain Classes of Children was passed through as legislation in 1897. This Act set out conditions for the immigration of juveniles to Canada, and forced the homes to obtain licenses to continue the movement. In order for the government to understand the children being brought into Ontario, they had to follow regulations:

An account of each child's background had to be produced and the account had to be kept up-to-date regarding character, habits, and so on, during the formative years. If such a child had a job and lost it, or changed to another, all the reasons had to be entered. In other words, a file, or dossier, was to be available for each child in the classified category. ${ }^{107}$

This Act made sure that children and agencies within Ontario were to be regularly inspected, and that children who came from Britain were not forgotten once they left the home. This Act led to similar laws being passed in other provinces, to ensure that all home children throughout Canada were maintained consistently. ${ }^{108}$

Through the personal stories of home children, the change in both feelings on child rearing and protecting the home children can be seen. There is a difference between the treatment

\footnotetext{
105 Jones and Rutman, In the Children's Aid, 17-18.

${ }^{106}$ Patricia T. Rooke and R.L Schnell, "Imperial Philanthropy and Colonial Response: British Juvenile Emigration to Canada, 1986-1930," Historian 46, no. 1 (November 1983): 65.

${ }^{107}$ Kohli, The Golden Bridge, 32-33.

${ }^{108}$ Kelley and Trebilcock, Making of the Mosaic, 92.
} 
of home children before the reform movement and afterwards within Canada. For example, Harry Jeffery was whipped and beaten at his first two homes, but as various inspection acts were passed, he was taken away from harsh conditions and was placed at a third farm where he was treated well and was very happy. ${ }^{109}$

One of the best examples of the change in treatment of a home child was Fred Roberts, the father of Ivy Sucee. In recollections of her father's experiences, Ivy describes the various homes her father lived in, and why he left or was taken away. After arriving in Canada in September 1898, Roberts spent twelve days at the Barnardo's receiving home in Toronto, and was then sent to live with the Spears family in Huntsville, Ontario. He was treated well by the family, but was taken back to the home after a year because Barnardo's did not want the children to become attached to a family in the early days after the Act to Regulate Immigration was passed. Roberts then went to Mrs. Jessup in Novar, Ontario where he was taught farm tasks, and was treated very kindly. He did not want to leave that home, but was forced to again after a year. When he was placed at his next home in Arthur, Ontario, Roberts was treated very harshly, and was beaten and mentally abused. The conditions were so bad that staff from Barnardo's came and took Roberts back to Toronto after a surprise visit to the farm revealed the poor conditions he was living under. Roberts believed that a neighbour who witnessed the poor treatment he received may have also reported the abuse that he was suffering. ${ }^{110}$ Fortunately, after being in a situation of such hardship, Roberts was placed with the Watkins family. They took him in and

\footnotetext{
${ }^{109}$ Harrison, The Home Children, 36-37.

${ }^{110}$ Ivy Sucee, Interview, July 31, 2007.
} 
raised him as their own son, and treated him with the utmost kindness. According to Ivy Sucee, Roberts was grateful for their kindness and love throughout his lifetime. ${ }^{11}$

There were many positive changes that took place in society and were aimed to protect home children. However, the attitudes of Canadians towards the juvenile immigrants were beginning to change towards the end of the $19^{\text {th }}$ century. There was a growing hostility towards these young workers in the $1880 \mathrm{~s}$ and those who influenced the press attempted to cast them in a negative light. Philip Bean and Joy Melville describe that after 1880, there was an increase in resentment towards migrant children until the end of the $19^{\text {th }}$ century. Patricia Rooke and R.L. Schnell describe how juvenile immigrants came to be considered "undesirables." Many Canadian workers believed that juvenile immigrants would act as competition to take the jobs to which Canadians felt entitled. This fear is most likely due to the rise and fall of the economy. When the economy went on a downturn and jobs were eliminated, individuals were more concerned with new immigrants taking the jobs that were available. Furthermore, the Canadian public, especially those harbouring Nativist views believed poor British children were unfit to come to Canada:

Beginning in the $1880 \mathrm{~s}$, the enlarged juvenile immigration movement was challenged by Canadians who opposed the importation of children and youths not on grounds of real or potential hardship and exploitation but because it represented an undesirable addition to the nation's population....these spokesmen of rural and town life identified juvenile immigrants as transmitters of the worst characteristics of Old World life, i.e., urban degeneracy, immorality, criminality, and syphilitic tendencies. In federal and provincial parliaments and representations to committees and commissions, they helped popularize beliefs regarding the undesirable nature of child immigrants. ${ }^{12}$

This concern with Nativism, or the opposition to immigration to ensure race purity was one that arose because Canadian workers both feared competition in the labour market, and harboured

\footnotetext{
${ }^{111}$ Ibid.

${ }^{112}$ Rooke and Schnell, "Imperial Philanthropy," 63.
} 
traditionally prejudiced viewpoints. The reasons for Canadians becoming disenchanted with the juvenile immigrants at several particular times in the past were economically based. To discourage competition, the workers emphasized that the children, being poor, would not be desirable Canadians.

Several historians have opinions of value on this matter. Patricia Rooke and R.L. Schnell state that trade unions, especially the Dominion Trades and Labour Congress, were in opposition to the juvenile immigration scheme because this type of immigration contributed to urban drift or the movement of people from rural to urban areas. In 1883, the union stated that the children, "not only competed with agricultural labour and Canadian dependent children for rural employment but also showed a decided preference for city life once their apprenticeships were served." ${ }^{113}$ That meant that there were fears that children who were being brought to Canada to take needed agricultural jobs were instead taking urban jobs from Canadians who wanted them. Neil Sutherland describes that the public hearings and report of Ontario's Royal Commission on the Prison and Reformatory System initiated negative public feelings about juvenile immigrants. He also demonstrates that the public had three major complaints with home children: “...they flooded the Canadian labour market and drove down wages; very many of them went wrong through hereditary traits; and they corrupted others with whom they associated, putting them up to all sorts of evil habits." ${ }^{114}$ Similarly, Kelley and Trebilcock explain how the home children were thought by Canadians to have brought "diseases" to Canada which arose from the "moral depravity of the British existence." 115 They also discuss how Canadians were prejudiced regarding this type of immigration and were quick to print negative stories of home children

\footnotetext{
${ }^{113}$ Ibid., 63.

${ }_{114}^{11}$ Sutherland, Children in English Canadian Society, 30.

${ }^{115}$ Kelley and Trebilcock, Making of the Mosaic, 92.
} 
although overall the government of Canada believed that the children brought to Canada were a great success. ${ }^{116}$

Many of the fears of Canadians were unsubstantiated and were based on economic cycles and social conditions, necessitating steps be taken to protect both Canadians and British children. Mentioned previously was the Act to Regulate Immigration passed in 1897. This was the precursor to the measures taken in 1899 to make the inspection of home children a more regulated process. In this year, the Department of the Interior, which was responsible for immigration at the time, created the position of Inspector of British Immigrant Children and Receiving Homes. ${ }^{117}$ George Bogue Smart was appointed to this position on January $1^{\text {st }}, 1900$, and retained this position until its dissolution in 1933. He was responsible for visiting the receiving homes throughout Canada and Great Britain and for organizing the inspection of juvenile immigrants throughout Canada. ${ }^{118} \mathrm{He}$ also published yearly reports based on the inspection records he received from his associates, which allowed people in both Canada and Britain to see the improvements occurring in the program with more regular and comprehensive inspection of the children.

G.B. Smart made his first report in 1901 to inform the public about the state of the juvenile immigration movement. He noted that over 40,000 children had come to Canada in the first 30 years of the movement and that their success had urged their friends in Britain to want to

\footnotetext{
${ }^{116}$ Ibid., 92.

${ }^{117}$ Kohli, The Golden Bridge, 30.

${ }^{118}$ Ibid., 30.
} 
come to Canada as well. ${ }^{119}$ Just one year after the instatement of his position, and four years after the Act to Regulate Immigration was passed, there was a great deal more consistency in the process to locate and inspect home children to make sure they were receiving appropriate care. G.B. Smart reported that with few exceptions, the children were receiving good treatment and that there was better judgement on the part of the agencies in the selection of homes for the immigrant children. ${ }^{120}$ G.B. Smart also publicized the work he was doing at various meetings throughout the province of Ontario. In 1905, he gave a talk at the Associated Charities Organization of Toronto and assured the crowd that supervision of the home children was much improved:

The prestige of the work depends on a continuous supervision over the children after they have been placed out on Canadian farms....First by systematic visitation... Second by regular correspondence.....Ill treatment is rare because the social habits of the country are such that any act of injustice towards a defenceless child would be quickly known and resented by people living in the neighbourhood. ${ }^{121}$

Throughout the many reports G.B. Smart wrote from 1901 until the termination of his position in 1933, he was adamant that the system of supervision in place for the home children was the best it could be, and that many children were happy and successful in their new lives in Canada. By 1908, G.B. Smart's report stated that changes in the system had been few since 1900 as the inspection seems to have been very successful. In 1907-1908 there were 1610 reports submitted on the treatment and conditions of the home children throughout Canada. 1397 of the reports stated the child was in a very good home and situation, 187 stated that the child was in a fair or

\footnotetext{
${ }^{119}$ Report of G.B. Smart 1901, Immigration Branch Records (hereafter cited as IBR), Record Group (hereafter cited as RG) 76 Immigration Series I-A-1, National Archives of Canada (hereafter cited as NAC), Volume 283, Reel C7832, File 236921, part 1, pg. 2.

${ }^{120}$ Report of G.B. Smart 1901, IBR, RG 76 Immigration Series I-A-1, NAC, Volume 283, Reel C-7832, File 236921 , part 1, pg. 3.

${ }^{121}$ George Bogue Smart, Paper read before the Associated Charities Organization of Toronto. March 17, 1905, Immigration Branch Records (hereafter cited as IBR), Record Group (hereafter cited as RG) 76 Immigration Series I-A-1, National Archives of Canada (hereafter cited as NAC), Volume 283, Reel C-7832, File 236921, part 1, pg. $10-11$.
} 
good home, while only 26 , or less than $2 \%$ of children, were in a doubtful or unsatisfactory home. ${ }^{122}$ In the small percentage of homes where the child was in a situation where they were being mistreated, action was taken. "When an inspector finds a boy or girl unsuited for work or the environment or the employer, the societies take prompt action and transfer the child to new surroundings." ${ }^{, 123}$ In his $1920-1921$ report, G.B. Smart described how the children seemed to be doing well because the inspectors ensured as many children as possible were visited:

The children were generally found contented and well settled and a very small number comparatively changed situations or had to be recalled on account of faulty traits of character on their own part during the year....Inspectors engaged constantly the year round, travelling in the townships, paying personal and unexpected visits amongst the children. Each child is privately interviewed and a careful survey is made of the home surroundings, personal appearance, and general progress. When complaints are received, the child and employer are brought together to determine differences. If the situation is unsatisfactory to the progress and well-being of the child, full particulars are reported to the superintendent of the home, and recommendations are given....this protects the interests of the children. ${ }^{124}$

Due to the vigilance of the inspectors, many children had their negative situation remedied before it became out of control and they were mistreated. The consistent visitation and the surprise visits also made it more difficult to hide problems, and allowed the child immigrants to explain their treatment in their own words to the inspectors. This can be demonstrated through an examination of the inspection records. There are thousands of inspection records, at least one for every juvenile immigrant who came to Canada between 1914 and 1930. Therefore it is impossible to examine them all. Of a random sample of 250 of these records however, a positive

\footnotetext{
${ }^{122}$ Overseas Report of G.B. Smart 1908, Overseas Settlement Office, Juvenile Migration Scheme, Empire Settlement Agreement, Immigration Branch Records (hereafter cited as OJEI), Record Group (hereafter cited as RG)76 Immigration Series I-A-1, National Archives of Canada (hereafter cited as NAC), Volume 200, Reel C7354/5, File 85203, pg. 13.

${ }^{123}$ Overseas Report of G.B. Smart 1908, OJEI, RG76 Immigration Series I-A-1, NAC, Volume 200, Reel C-7354/5, File 85203,pg. 15.

${ }_{124}$ Report of G.B Smart 1920-1921, Personal Papers of George Bogue Smart (hereafter cited as PPGBS), Record Group (hereafter cited as RG)76 Immigration Series I-A-1. National Archives of Canada (hereafter cited as NAC), Volume 170, Reel C-7327, File 54087 part 1,pg. 13-14.
} 
pattern emerges. Of the 250 , none of the children received a rating of unsatisfactory for their treatment. All but six reports stated the child was well-treated by their employer. ${ }^{125}$ The system in place throughout the first three decades of the $20^{\text {th }}$ century ensured that many children were well looked after by their Canadian employers, and that they were able to be happy and successful in their new life in Canada.

Leslie Coombes was a home child who experienced the effects of the improved inspection system and concern for children present in Ontario society. He came to Bowmanville, Ontario at the age of fourteen in 1922 to live with the Werry family, and quickly found his place within farm life. He was very fortunate to be treated as a member of the family, with his own room in the house and three square meals a day. He was also paid a fair wage which increased each year that he worked on the farm for Mr. Werry. Having contact with both the home and other home children, Coombes believed he was treated "like a prince," and he was not singled out for being a child immigrant. ${ }^{126} \mathrm{He}$ was never treated poorly, and he also never knew of any other home children at the time in the area who were mistreated. He worked on the farm until he was twenty years of age when Mr. Werry could no longer afford to pay him what he deserved, but always appreciated the excellent start in life that the Werrys had given him. Over the years on the farm, Coombes was regularly inspected by the local inspector who worked under G.B. Smart. Mr. Black came to visit five separate times, each year from 1923 until 1927 when Coombes had reached nineteen years of age. Each time, the report stated that Coombes had a fine home, he was of good character, and that the family was satisfied with his work. ${ }^{127}$ Not only was

\footnotetext{
${ }^{125}$ Juvenile Inspection Reports, Record Group (hereafter cited as RG)76 Immigration Series C4C, National Archives of Canada (hereafter cited as NAC), 1913-1932, Reels T15420-T15427.

${ }^{126}$ Letter from Leslie Coombes to Mr. Merry of the Marchmont Home in Belleville, Ontario, 1923.

127 Juvenile Inspection Reports, RG76 Immigration Series C4C, NAC, 1913-1932, T15421.
} 
Coombes treated kindly and led to be successful in Canada, but his three brothers also came to Canada as home boys, and were in similar situations. His brother Eric was sent to the Carruthers farm just over a mile down the road, his brother Cyril went to another Bowmanville farm nearby, while the youngest brother Reg took over Leslie's position at the Werry farm when he was too old to continue as a home boy. Each of the brothers had excellent treatment and care at their respective positions, and suggest that the regular inspection of home children ensured children were well taken care of.

The publicity and reassurances from the G.B. Smart reports ensured there was a great deal of support within Canada and Britain regarding child emigration. This can also be seen within Britain as new homes for children were constructed, and immigration from industrial schools increased. ${ }^{128}$ The continued approval and necessity of the program can be demonstrated through the demand for greater numbers of children throughout Canada. Over the first six years of the $20^{\text {th }}$ century, the numbers of both juvenile immigrants and applications for their services dramatically increased. In the period of 1900-1901, there were almost six thousand applications for the nearly one thousand children who came to Canada in that period. By 1903-1904 there were over 16,000 applications for home children, and the number of children arriving in Canada also rose to 2200 in that twelve month period. Finally, before the interest in the program ebbed once again, the number of children arriving in Canada in 1906-07 rose to a high of over 3500 children with a total of nearly 20,000 applications for their services. ${ }^{129}$ According to immigration historians Ninette Kelley and Michael Trebilcock, over 33,500 children emigrated from Britain between 1900 and 1915: half coming from the Barnardo organization, with over 300,000

\footnotetext{
${ }^{128}$ Parr, Labouring Children, 144.

${ }^{129}$ Report of G.B Smart 1920-1921, PPGBS, RG76 Immigration Series I-A-1, NAC, Volume 170, Reel C-7327, File 54087 part 1, pg. 11.
} 
applications for their services received. ${ }^{130}$ It was because of this incredible demand that the Canadian government continued to approve of the program.

Unfortunately the promise of the first few decades of the 1900s was quickly lost, as policies to curb the immigration of children were enacted in Canadian society. In 1912, the Adolescent Act came into effect, raising the school-leaving age within Ontario to sixteen. This prompted many agencies to restrict the ages of children they brought to Canada and therefore caused child emigration to substantially slow. ${ }^{131}$ Another change in immigration policy that affected juvenile immigration was the Empire Settlement Agreement which came into effect in 1922. This agreement offered transportation assistance to agriculturalists and their families, farm labourers, domestics, and juvenile immigrants over the age of fourteen. ${ }^{132}$ The province of Ontario entered into an agreement with Britain to ensure more boys and girls between the ages of fourteen and eighteen came to the province to live and work. These juveniles received monetary assistance for their passage to Canada, and the requirement that they attend school until the age of sixteen was waived. ${ }^{133}$ The Overseas Settlement Committee believed that an annual settlement of juveniles aged fourteen to eighteen ten times the number previously brought over would be most beneficial for the Canadian nation. ${ }^{134}$ Canada was going through a period of strong economic growth, and was extremely dependent upon juveniles who could perform agricultural

\footnotetext{
${ }^{130}$ Kelley and Trebilcock, Making of the Mosaic, 124.

${ }^{131}$ Kohli, The Golden Bridge, 33.

${ }^{132}$ Kelley and Trebilcock, Making of the Mosaic, 189.

${ }^{133}$ Kohli, The Golden Bridge, 35.

${ }^{134}$ R.L. Schnell, "The right class of boy: youth training schemes and assisted emigration to Canada under the Empire Settlement Act, 1922-39," History of Education 24, no. 1 (1995): 76-77.
} 
labour for a minimal wage. This scheme was responsible for bringing over more juvenile immigrants per year in the late 1920 s than in any previous year. ${ }^{135}$

When the Canadian economy took a downturn after the Depression began in 1929, the numbers of juvenile immigrants arriving in Canada each year began to decline. By 1933, the unemployment, severe competition for any remaining jobs, and poor economic conditions intensified by the Depression "virtually stopped the movement." ${ }^{\text {"136 }}$ From a high of 4281 children arriving in Canada in 1929-1930, the numbers quickly dropped. Half that number arrived just one year later, and by 1932-1933 only one hundred seventy-two children arrived in Canada. Between 1933 and 1939, the number of children arriving each year levelled off at approximately ten to forty per year. ${ }^{137}$ By the beginning of the Second World War, the movement was at an end, and juvenile immigration to Canada on any large scale never resumed. ${ }^{138}$

Throughout the juvenile immigration movement between 1868 and 1939, Canada underwent many social and political changes regarding the care of children. These changes impacted the treatment of the home children, and caused people to vary their opinions on the movement and the children themselves. Children from overseas were often looked down upon when the Canadian people were going through difficult times, and their negative feelings led to the mistreatment of children during these periods of stress. With the various protection measures put into place in the late $19^{\text {th }}$ and early $20^{\text {th }}$ centuries, the home children were treated more

\footnotetext{
${ }^{135}$ Report of G.B Smart 1920-1921, PPGBS, RG76 Immigration Series I-A-1, NAC, Volume 170, Reel C-7327, File 54087 part 1, pg. 11.

${ }^{136}$ Schnell, "The right class," 88.

${ }^{137}$ Total Number of Juvenile Arrivals Through Organizations From 1920, Personal Papers of George Bogue Smart (hereafter cited as PPGBS), Record Group (hereafter cited as RG)76 Immigration Series I-A-1, National Archives of Canada (hereafter cited as NAC), Volume 170, Reel C-7327, File 54087 part 1.

${ }^{138}$ Kohli, The Golden Bridge, 36.
} 
kindly, as there were repercussions for those who did not respect children in the manner befitting the day. Furthermore, a greater sense of morality and responsibility was developing throughout the nation. Without more case studies on Canadian children it is impossible to compare the treatment of home children to their Canadian counterparts. However, it can be seen that the poor treatment immigrant children faced was not due solely to the malice of certain Canadian farmers, but rather outside forces such as economic stress. Canadian children were not all treated kindly either. The mistreatment of both Canadian and immigrant children in the mid to late $19^{\text {th }}$ century was because there were no social policies in place for how to deal with children in an appropriate manner until much later. The increase in free and compulsory education, quality of life, and a host of other factors gradually made people more aware of social ills and enabled home children to receive better treatment.

It can also be demonstrated through the improvement in supervision and inspection of home children that their overall treatment improved over time and allowed many to live a happy and productive life in Canada. This paper is important to understand why the home children were treated in the manner that they were. It was not one factor which led to success or failure, nor one person who made the difference between mistreatment and kindness. Rather, the treatment of home children was based upon the changing values of a nation in its early days, attempting to deal with its growth and maturity. Keeping quiet about child rearing was popular at Confederation, but as the nation changed, the lives of children were viewed as more valuable, and child welfare became a public rather than a private matter. The children who arrived from Britain between 1868 and 1939 to start a new life in a new country were helping the nation to change their opinions on children. There were issues and problems to be worked out within this 
seventy one year period, and occasionally these children were caught in the middle. These juvenile immigrants played an essential role in the development of rural and urban Canada, and ensured that this country had a positive beginning. Because of this important and special group of child immigrants, there are today over one million descendents in Canada ensuring that the nation continues to change and grow. 


\section{Bibliography}

\section{Primary Documents}

Coombes, Leslie. Letter to Mr. Merry of the Marchmont Home in Belleville, Ontario, 1923.

Coombes, Rowlie. Interview. July 17, 2007.

George Bogue Smart, Paper read before the Associated Charities Organization of Toronto. March 17, 1905. Immigration Branch Records. Record Group76 Immigration Series I-A1. National Archives of Canada. Volume 283, Reel C-7832, File 236921, part 1.

Juvenile Inspection Reports. Record Group76 Immigration Series C4C. National Archives of Canada. 1913-1932. Reels T15420-T15427.

Report of G.B. Smart 1901. Immigration Branch Records. Record Group76 Immigration Series I-A-1. National Archives of Canada. Volume 283, Reel C-7832, File 236921, part 1.

Report of G.B. Smart 1908. Overseas Settlement Office, Juvenile Migration Scheme, Empire Settlement Agreement, Immigration Branch Records. Record Group76 Immigration Series I-A-1. National Archives of Canada. Volume 200, Reel C-7354/5, File 85203.

Report of G.B Smart 1920-1921. Personal Papers of George Bogue Smart. Record Group76 Immigration Series I-A-1. National Archives of Canada. Volume 170, Reel C-7327, File 54087 part 1.

Report of G.B. Smart 1922-1923. Personal Papers of George Bogue Smart. Record Group76 Immigration Series I-A-1. National Archives of Canada. Volume 170, Reel C-7327, File 54087 part 1.

Sucee, Ivy. Interview. July 31, 2007.

Total Number of Juvenile Arrivals Through Organizations From 1920. Personal Papers of George Bogue Smart. Record Group76 Immigration Series I-A-1. National Archives of Canada. Volume 170, Reel C-7327, File 54087 part 1.

$\underline{\text { Secondary Sources }}$

Axelrod, Paul. The Promise of Schooling: Education in Canada, 1800-1914. Toronto: University of Toronto Press, 1997.

Bagnell, Kenneth. The Little Immigrants: The Orphans Who Came to Canada. New Edition. Toronto: The Dundurn Group, 2001.

Bean, Philip and Joy Melville. Lost Children of the Empire. London: Unwin Hyman, 1989. 
Boyle, Shirley E. "An analysis of the Social Mores of Canadians 1869-1924 as demonstrated in their Treatment of the Home Children." MA research essay, Carleton University, 1997.

Corbett, Gail H. Nation Builders: Barnardo Children in Canada. $2^{\text {nd }}$ Ed. Toronto, Dundurn Press, 2002.

Davey, Ian E. "The Rhythm of Work and the Rhythm of School." In Histories of Canadian Children and Youth, edited by Joy Parr and Nancy Janovicek, 108-121. Toronto: Oxford University Press, 2003.

Harrison, Phyllis, ed. The Home Children. Manitoba: Watson and Dwyer Publishing Ltd., 1979.

Jones, Andrew and Leonard Rutman. In the Children's Aid: J.J. Kelso and Child Welfare in Ontario. Toronto: University of Toronto Press, 1981.

Kelley, Ninette and Michael Trebilcock. The Making of the Mosaic, A History of Canadian Immigration Policy. Toronto: University of Toronto Press, 1998.

Kirby, Peter. Child Labour in Britain, 1750 - 1870. New York: Palgrave MacMillan, 2003.

Kohli, Marjorie. The Golden Bridge: Young Immigrants to Canada, 1833-1939. Toronto: Natural Heritage Books, 2003.

Magnusson, Anna. Quarriers Story, One man's Vision That Gave 7,000 Children a new Life in Canada. Toronto: Dundurn Press, 2006.

Parr, Joy. Labouring children: British Immigrant Apprentices to Canada, 1869-1924. Montreal: McGill-Queen's University Press, 1980.

Prentice, Alison. The School Promoters: Education and Social Class in Mid-nineteenth Century Upper Canada. Toronto: McClelland and Stewart Limited, 1977.

Rooke, Patricia T. and R.L Schnell. "Imperial Philanthropy and Colonial Response: British Juvenile Emigration to Canada, 1986-1930." Historian 46, no. 1 (November 1983): 5677.

Schnell, R.L. "The right class of boy: youth training schemes and assisted emigration to Canada under the Empire Settlement Act, 1922-39." History of Education 24, no. 1 (1995): 7390.

Sutherland, Neil. Children in English Canadian Society, Framing the Twentieth-Century Consensus. Toronto: University of Toronto Press, 1976.

Wagner, Gillian. Barnardo. London: Weidenfeld and Nicolson, 1979.

Wagner, Gillian. Children of the Empire. London: Weidenfeld \& Nicolson, 1982. 